* Mestre em Direito Penal pela Universidade de Coimbra. Especialista em Direito Penal Econômico Europeu pelo Instituto de Direito Penal Econômico Europeu - da mesma instituição. Especialista em Direito Penal e Criminologia pela UFPR. Especialista em Direito Constitucional pela ABDCONST. Especialista em Sociologia Política pela UFPR. E - $m$ a $\mathrm{i} 1$ : cris_9805@hotmail.com ** Mestre em Direito Constitucional pela Faculdade de Direito da Universidade de Coimbra. Pós-Graduanda em nível de Especialização em Direito do Estado - Área de Concentração em Direito Tributário pela mesma instituição. Pós-Graduada em Direito e Processo do Trabalho pela Universidade Anhanguera. Email:stecunha@hotmail.com

\section{A Perda do Direito de Sufrágio Ativo como Efeito da Condenação Penal: uma abordagem comparada entre Brasil e Portugal}

\author{
Loss of the Right of Suffrage as Effect of \\ Criminal Sentence: A COMPARATIVE APPROACH \\ Between Brazil and Portugal
}

\author{
Cristina Rego Oliveira * \\ Stella Furlanetto Mattos Cunha **
}

Resumo: O texto realizará uma comparação entre o regime jurídico do direito à participação política do preso no Brasil e em Portugal. Inicialmente, serão apresentados os conceitos de dignidade, cidadania, sufrágio e participação popular. Em seguida, será destacado que, no ordenamento português, a restrição do direito de voto não é automaticamente aplicada na sentença condenatória, sendo aplicado somente em casos excepcionais, observando a lógica da funcionalidade da pena. Em seguida, a problemática será abordada no sistema legislativo pátrio, no qual, como é notório, a cassação dos direitos políticos é aplicada de forma automática. Ao final, será destacada a situação do preso provisório, que, a despeito de não possuir uma decisão definitiva, tem também o seu direito cerceado.

Palavras-chave: Dignidade. Direitos políticos. Cidadania. Sufrágio universal. Direito de voto. Condenado. Pena acessória. Pena automatica.

Abstract: The text will make a comparison between the legal regime of the right to political participation that sentenced people in Brazil and Portugal. Initially, we'll introduce the concepts of dignity, citizenship, suffrage and popular participation. Then it will be noted that, in order Portuguese, the restriction of voting rights is not automatically applied to the sentence, thus meeting, before cases and in a reasoned manner, the logic of proportionality and the functions of punishment. Then the problem will be addressed to our legislative system, in which, as is well known, the cassation of political rights is automatically applied. In the end, will be detach the situation of the prisoner provisional that, despite not having a final decision has curtailed their rights.

Keywords: Dignity. Political rights. Citizenship. Universal suffrage. Right to vote. Sentenced person. Automatic and assessory penalty. 


\section{INTRODUÇÃO}

O ensaio apresenta uma análise comparativa acerca do exercício do sufrágio no Brasil e em Portugal, avaliando como tal direito é garantido aos sujeitos inseridos no sistema de justiça criminal, sejam eles detidos de forma provisória ou definitiva.

Inicialmente, será feita uma abordagem conceitual acerca da ideia de dignidade de pessoa humana e de sua vinculação com o direito de participação política dos sujeitos, aduzindo, ao final, como o exercício do "voto" deve ser tido como o sustentáculo para o Estado Democrático de Direito.

Após uma conceituação preliminar, serão apresentadas as peculiaridades do ordenamento jurídico Português, destacando que a sanção de perdimento dos direitos políticos não pode ser aplicada de forma automática pela sentença condenatória, mas, do contrário, deverá o magistrado observar, diante das peculiaridades do caso concreto, de que forma o "voto" exercido pelo condenado colocará em risco a estrutura do Estado de Direito.

Ao final, demonstrar-se-á que, no Brasil, a situação dos sujeitos detidos é ainda mais ofensiva aos princípios democráticos, uma vez que a suspensão dos direitos políticos é medida constitucionalmente prevista, alcançando todos àqueles que possuem, em seu desfavor, sentença condenatória transitada em julgado. Ademais, será destacado que até mesmo os presos provisórios são cerceados de seu direito a participar na escolha de seus representantes.

\section{DIGNIDADE DA PESSOA HUMANA COMO FUNDAMENTO DO ESTADO DEMOCRÁTICO CONSTITUCIONAL: HÁ SUJEITO DE DIREITO SEM CIDADANIA?}

\subsection{A República e o Princípio da Dignidade da Pessoa Humana}

Inúmeras são as tentativas conceituais dispensadas ao vocábulo "dignidade", mas pode-se afirmar que o ponto convergente dessas plúrimas significações reside na ideia comum de ser "tida como valor supremo consolidado no texto constitucional, e que deve informar todo o sistema jurídico." (SARLET, 2006, p. 66). Nesse sentido, "os valores da Lei Fundamental tem seu ponto central para a comunidade social no livre desenvolvimento da personalidade e da dignidade, razão pela qual o mandamento de inviolabilidade da dignidade do homem é base de todos os direitos fundamentais" (HARBELE, 2008, p.183). 
Desde logo, tal concepção transporta-se também para a proteção de um conjunto de valores civilizatórios incorporados ao patrimônio constitutivo do sujeito: ao proibir que seja tratado como mero objeto e instrumento do Estado, protege-se sua autonomia, especialmente destacável no quadro das liberdades públicas e das prerrogativas que possibilitam o exercício de direitos políticos.

Ao termo dignidade imputam-se valores positivos que constituem as relações sociais, tais como a noção de respeito e de pertencimento. Nesse sentido, de acordo com a doutrina, a dignidade pode também ser tida como atributo

[...] espiritual e moral inerente a pessoa, que se manifesta singularmente na auto-determinação consciente e responsável da própria vida e que traz consigo a pretensão ao respeito por parte dos demais, constituindo-se em um mínimo invulnerável que todo estatuto jurídico deve assegurar, de modo que apenas excepcionalmente possam ser feitas limitações ao exercício dos direitos fundamentais, mas sempre sem menosprezar a necessária estima que merecem todas as pessoas enquanto seres humanos (MORAES, 2002, p.128-129).

Nos Estados Democráticos, a dignidade da pessoa humana é tida como postulado basilar no qual se sustenta a República e, como conseqüência, a organização do poder político. Convém salientar que República significa uma “comunidade política, uma 'unidade coletiva' de indivíduos que se autodeterminam politicamente através da criação e manutenção de instituições políticas próprias assentes na decisão e participação dos cidadãos no governo dos mesmos" (CANOTILHO, 2003, p.224).

Fala-se em dignidade da pessoa, pois o indivíduo é reconhecido como limite e fundamento do domínio político. Assim, a República “é uma organização política que serve aos homens e não é o homem que serve os aparelhos políticos organizatórios" (CANOTILHO, 2003, p.225). A Constituição confere uma unidade de sentido, de valor e de concordância prática ao sistema de direitos fundamentais.

A dignidade da pessoa humana é a prima facie da República, diz Jorge Miranda, e sobre o tema procura esclarecer que quando se fala que a comunidade política baseia-se na dignidade da pessoa humana quer dizer que a Lei Fundamental afasta e repudia qualquer tipo de interpretação que estiver associada à sacrifícios de direitos, afinal é sob o manto deste princípio que se decide pela garantia dos direitos fundamentais dos cidadãos (preâmbulo) e pela interpretação 
e integração dos preceitos constitucionais e legais sobre os direitos em harmonia com a Declaração Universal dos Direitos do Homem.

Nesse sentido temos a prescrição do artigo 29, n. $^{\circ} 2$ da Declaração Universal dos Direitos do Homem, apontando que no gozo dos direitos e liberdades ninguém está sujeito senão as limitações estabelecidas pela lei, com vista exclusivamente a promover o reconhecimento e o respeito dos direitos e liberdades dos outros, a fim de satisfazer as justas exigências da moral, da ordem política e do bem-estar numa sociedade democrática. Cumpre ressaltar que não é qualquer exigência da moral (social), da ordem pública e do bemestar que podem impor limites, pois primeiramente tais exigências deverão ser observadas no contexto de uma sociedade democrática, implicando na "inadmissibilidade de privação, restrição ou suspensão de direitos por exercício contrário à sociedade democrática ou às finalidades da Constituição" (MIRANDA, 2008, p.174-175).

O princípio da participação democrática na vida coletiva - seja sob o ponto de vista dos direitos políticos, ou ainda enquanto condição do sistema democrático - tem seus alicerces no respeito e na garantia dos direitos e liberdades fundamentais, os quais possuem sua fonte ética na dignidade da pessoa, de todas as pessoas. Tudo isso para dizer que a participação não é prevista pela simples participação, mas sim enquanto "expoente de realização das pessoas" (MIRANDA, 2008, p.198).

\subsection{A Participaçao Política como Direito Fundamental}

De acordo com Peter Härbele, a "base do Estado Constitucional é dupla: soberania popular e dignidade do homem" (HARBELE, 2008, p.208). Dessa relação que se constitui entre pessoa e Estado denota-se uma vinculação possível de ser exteriorizada, de forma inclusivamente jurídica, através da titularidade da manifestação política: tal correlação, emanada da ficção contratualista de Rousseau, pressupõe que todo poder emana do povo, que através da escolha livre de seus representantes autoriza sua representação por terceiros no quadro institucional do ente que constitui.

Nesse passo, o "cidadão" surge como titular de direitos fundamentais e personagem central do Estado, perfazendo uma relação de pertença ou de integração numa determinada comunidade. Isso porque, o exercício de suas vontades pressupõe a ideia de participação na gerência da vida do ente. Como reflexo da dignidade, resta evidenciada a qualidade de autonomia pessoal que 
lhe é inerente: sua consolidação demonstra-se através da liberdade de expressão, e em especial, de participação política.

A participação política constitui um elemento essencial das democracias contemporâneas, pois é simultaneamente parte integrante e sustentáculo do princípio democrático, constitucionalmente garantido, de modo que a democracia é impensável sem a capacidade dos cidadãos participarem livremente do processo de governo. E ainda podemos dizer que os direitos políticos ou de participação política são direitos de cidadania, direitos dos indivíduos enquanto cidadãos, enquanto membros da república, da coletividade politicamente organizada (CANOTILHO; MOREIRA, 2007, p.664).

A participação política é a vertente dinâmica da autodeterminação política que se concretiza através das formas previstas na Constituição, essa intervenção deve ser política como expressão da soberania, ou seja, quando os cidadãos se manifestam diretamente ou através dos seus representantes sobre a aprovação ou não de uma norma jurídica ou sobre uma decisão política.

Ora, através da participação política que será garantido que o governo venha decidir, abstrata ou concretamente de acordo com a vontade do povo. Seria ideal que todos pudessem participar diretamente, mas diante da impossibilidade, opta-se pela prática preferencial da intermediação de representantes, os quais presumidamente decidirão de acordo com a vontade do povo.

Diferentemente da Alemanha, França e Itália, Portugal prevê a participação política como direito fundamental. Tendo em vista a abstração do conteúdo deste direito, deve-se considerá-lo sob a ótica da autodeterminação política dos indivíduos e, para que tal seja possível, o ordenamento garante a intervenção nos assuntos políticos, diretamente ou por intermédio de representantes eleitos com liberdade em eleições periódicas e através do sufrágio universal.

Os direitos fundamentais exercem funções imprescindíveis em um Estado Democrático na medida em que são considerados simultaneamente pressuposto, garantia e instrumento do princípio democrático da autodeterminação do povo por intermédio de cada indivíduo, "mediante o reconhecimento do direito de igualdade (perante a lei e oportunidade), de um espaço de liberdade real, bem como por meio da outorga do direito à participação (com liberdade e igualdade)" (SCHNEIDES apud SARLET, 2006, p. 72-73). Tanto é assim que a positivação e a garantia do efetivo exercício de direitos políticos (no sentido de participação e conformação do 
status político) podem ser considerados o fundamento funcional da ordem democrática.

Ademais, a liberdade de participação política do cidadão, participação esta considerada como a possibilidade de intervenção no processo decisório através do exercício de efetivas atribuições inerentes à soberania, tais como, o direito de voto, o igual acesso aos cargos públicos, etc., constitui complemento indispensável das demais liberdades.

O Direito de Participação Política exerce funções diversificadas na ordem jurídica, em face das limitações deste estudo, opta-se por traçar em linhas gerais algumas dessas funções diante da dupla dimensionalidade dos direitos fundamentais.

Os direitos fundamentais revelam duas perspectivas, também denominada dimensões: a subjetiva, que tem como foco principal o indivíduo, gerando direitos subjetivos aos seus titulares e a objetiva, que pode ser visualizada no seu aspecto axiológico, como expressão de ordem de valores fundamentais objetivos (dimensão valorativa ou funcional) ou no sentido de sua mais-valia, isto é, no reconhecimento de efeitos jurídicos autônomos, ou melhor, como um reforço da juridicidade das normas de direitos fundamentais.

Em suma, a dupla dimensionalidade dos direitos fundamentais admite que estes direitos não se limitem à função precípua de serem subjetivos de defesa dos indivíduos contra atos do poder público, indo além, ou seja, "constitui função axiologicamente vinculada, demonstrando que o exercício dos direitos subjetivos está condicionado de certa forma, ao seu reconhecimento pela comunidade na qual se encontra inserido" (SARLET, 2006, p.168-169).

Ligado à dimensão objetiva-valorativa dos direitos fundamentais temos a denominada eficácia dirigente em relação aos órgãos estatais no sentido de que a este incumbe a obrigação permanente de realização e concretização dos direitos fundamentais (SARLET, 2006, p.171).

A eficácia irradiante também deriva da dimensão objetiva-valorativa dos direitos fundamentais e nesta os direitos fundamentais fornecem impulsos e diretrizes para a aplicação e interpretação do direito infraconstitucional e, além disso, aponta para a necessidade de uma interpretação conforme os direitos fundamentais (SARLET, 2006, p.171).

Os direitos políticos como direito de participação na atividade estatal e na condução do interesse público pressupõe a posição ativa do indivíduo, ocupando no sistema constitucional o catálogo dos direitos, liberdade e garantias, embora afirme Vieira de Andrade que os direitos de participação seriam um 
misto de direitos de defesa e de direitos a prestações, mas que são autonomizados em razão da sua função de garantia de participação individual na vida política, mais concretamente, na formação da vontade política da comunidade ${ }^{1}$.

De acordo com Sarlet (2006, p.206) os direitos políticos devem ser inseridos no grupo funcional dos direitos de defesa, ou segundo Alexy (2008), no âmbito dos direitos prestacionais especificamente entre os direitos de participação à organização e procedimento.

Afirma Klaus Stern que os direitos (liberdades) políticos não podem ser desvinculados dos direitos pessoais de liberdade, constituindo juntamente com este uma espécie de status global da liberdade (STEM apud SARLET, 2006, p.206). A opção pelos direitos de defesa justifica-se pela relação inevitável entre direitos políticos e direitos pessoais de liberdade.

Os direitos políticos não podem ser dissociados de sua titularidade e exercício. A cidadania é a posição política do indivíduo e a possibilidade do exercício de direitos. O status civitatis ou estado de cidadania implica uma situação subjetiva, esparzindo os direitos e deveres de caráter público das pessoas que se vinculam ao Estado. Através da democracia representativa, denota-se a possibilidade de se eleger e de ser eleito, viabilizada por diversos mecanismos institucionais aptos a expressar a liberdade de manifestação dos sujeitos, tais como através do sufrágio, no referendo, bem como na constituição de partidos.

Diante disso, pergunta-se: basta um cidadão ter a titularidade do direito de sufrágio ativo e não poder exercê-lo? A resposta é negativa, pois a titularidade por si só não permite que o cidadão participe da vida política escolhendo seus representantes de acordo com as propostas por eles apresentadas não podendo influir no futuro político do Estado.

Ademais disso, nas democracias modernas as prerrogativas inerentes à cidadania ultrapassam o mero direito de escolher seus governantes: a concepção atual deixa de vincular-se especificamente ao exercício de prerrogativas políticas. Contagiado pelos efeitos originários da pós-modernidade, também o conteúdo do termo autoriza o pensamento de uma sua versão cosmopolita, traduzida no respeito pelas diferenças fundantes do espaço público. Nesse sentido, ser cidadão também se expressa no modo ético de existir que implica na abertura à alteridade

\footnotetext{
${ }^{1}$ Vieira de Andrade sustenta a natureza mista dos direitos políticos, pois a liberdade de exercer o voto, que inclui o direito de exigir a abstenção de interferências indevidas (dimensão defensiva), abrange também a faculdade de exigir a atuação positiva do Estado, seja para garantir a proteção do livre exercício dos direitos políticos contra terceiros (direitos de proteção), seja para o fornecimento dos recursos materiais para tanto tais como listas de votação, os boletins de voto, a organização das mesas, etc. Cfr. Os Direitos Fundamentais [...]. (ANDRADE, 2001, p.175).
} 
do outro ou de si mesmo: isto torna imprescindível a ação de "escutar" o diferente, especialmente àquele que está marginalizado do contexto social, tal qual o sujeito delinqüente. Isso porque, não basta uma cidadania apenas formal no sentido de estar "oficialmente" incluído, de "participar" no sentido de ter direito ao voto.

Segue-se, então, a narrativa acerca de como os sujeitos delinquentes são tratados no ordenamento jurídico nacional e estrangeiro, apontando suas principais características e diferenças.

\section{DIREITO DE SUFRÁGIO DOS SUJEITOS CONDENADOS EM PORTUGAL}

$\mathrm{O}$ artigo $10^{\circ}, \mathrm{n}^{\circ} 1$ da Constituição Portuguesa estabelece que o povo exerce o poder político através do sufrágio universal, concretizando-se o princípio democrático no artigo $1^{\circ}$ (vontade popular), artigo $2^{\circ}$, (Estado de direitos democrático), artigo $3^{\circ}$ (a soberania reside no povo) e o artigo $108^{\circ}$ (o poder político pertence ao povo). Assim sendo, o sufrágio deve, então, ser entendido como a intervenção mediante o voto, sobretudo em eleições dos titulares de cargos políticos (CANOTILHO; MOREIRA, 2007, p.285).

Acompanhando as palavras da doutrina, a manifestação da vontade popular não reveste uma forma unívoca na Constituição. Entretanto, a maior expressão da vontade popular é, sem dúvida, e acima de todas, o sufrágio eleitoral e o referendo, não impedindo, embora em diferente relevo, as múltiplas formas de expressão política (CANOTILHO; MOREIRA, 2007, p.200).

O direito de sufrágio ${ }^{2}$ pode ser compreendido sob dois aspectos: o primeiro é o direito de sufrágio ativo, que consiste no direito de votar, de participar das eleições, o segundo é o direito de sufrágio passivo, que garante o direito de ser eleito para exercer um cargo público.

\footnotetext{
${ }^{2}$ Por sua vez o sufrágio é dotado de determinadas características, é individual, pois constitui um direito dos indivíduos, com exclusão do sufrágio orgânico ou familiar, típico dos sistemas políticos corporativos arcaicos; é universal, ou seja, constitui direito de todos os cidadãos admitindo exclusão pela lei por motivo constitucionalmente admitidos, não sendo possível qualquer restrição com fundamento no estatuto social, em requisitos patrimoniais, literários; é igual, isto é, cada cidadão tem apenas um voto e os votos tem eficácia idêntica, sendo vedado votos plúrimos, nem votos de efeitos qualificados; é direto, porque cabe aos cidadãos escolherem sem instâncias intermediadoras (ex. colégios eleitorais) os titulares de cargos políticos; é secreto já que o modo pelo qual é exercido não se permite identificar a escolha do eleitor e nem tampouco este é obrigado a revelá-la e o sufrágio é periódico afinal os mandatos obtidos através do sufrágio não são vitalícios, nem por tempo indeterminado, mas sim por períodos certos previamente conhecidos. As características do sufrágio foram extraídas de Canotilho e Moreira (2007, p.285-286).
} 
O sufrágio é um instrumento fundamental de realização do princípio democrático, visto que através dele se legitima democraticamente a conversão da vontade política em posição de poder e de domínio, estabelece-se a organização legitimante de distribuição de poderes, procede-se à criação do pessoal político e marca-se o ritmo da vida política de um país.

Além de ser um componente do princípio democrático da Constituição, o direito de sufrágio é também um direito fundamental dos cidadãos gozando do regime dos "direitos, liberdades e garantias". Assim sendo, os princípios da universalidade e da igualdade estabelecidos no artigo $100^{\circ}$ são conseqüências da aplicação objetiva dos mesmos princípios que regem todos os direitos fundamentais, quais sejam, o princípio da universalidade e o princípio da igualdade.

$\mathrm{O}$ artigo $49^{\circ}$ da Constituição Portuguesa estabelece que, "têm direito de sufrágio todos os cidadãos maiores de dezoito anos, ressalvadas as incapacidades previstas na lei geral", ou seja, o direito de sufrágio assiste a todos maiores de 18 anos - princípio da universalidade do sufrágio. Ocorre que este princípio não exclui a possibilidade de incapacidades eleitorais: segundo o entendimento de Canotilho, tais incapacidades se referem a incapacidades civis, de maneira a vedar o exercício de sufrágio apenas aos incapazes segundo a lei civil, os interditos e não diz respeito a incapacidades jurídico-públicas (CANOTILHO; MOREIRA, 2007, p.285-286).

O princípio da universalidade comum aos direitos fundamentais nos remete ao entendimento de que "todos quantos fazem parte da comunidade política fazem parte da comunidade jurídica, são titulares de direitos e deveres aí consagrados" (MIRANDA, 2008, p.231).

O princípio da universalidade do sufrágio proíbe a discriminação à medida que veda a exclusão injustificada dos cidadãos da participação eleitoral. Nesse sentido, tal princípio é aplicável nas hipóteses de inconstitucionais restrições ao direito de sufrágio por serem desnecessárias e desproporcionadas.

De acordo com as Leis Eleitorais em vigor ${ }^{3}$, não gozam de capacidade eleitoral ativa: os interditos por sentença com trânsito em julgado; os notoriamente reconhecidos como dementes, ainda que não interditos por sentença, quando internados em estabelecimento psiquiátrico ou como tais

\footnotetext{
${ }^{3}$ Tratam das incapacidades eleitorais ativas: o artigo $2^{\circ}$ da Lei Eleitoral da Assembléia Legislativa da Região Autônoma dos Açores - Decreto-Lei 267/80, de 8 Agosto, o artigo $2^{\circ}$ da Lei Eleitoral para a Assembléia da República - Lei n. ${ }^{\circ} 14 / 79$, de 16 Maio, o artigo $3^{\circ}$ da Eleição para os Órgãos das Autarquias Locais - Lei Orgânica n..$^{\circ}$ 1/2001, de 14 de Agosto e o artigo $3^{\circ}$, n. 2 da Eleição para o Presidente da República- Decreto - Lei n ${ }^{\circ} 319-\mathrm{A} / 76$, de 3 de Maio.
} 
declarados por uma junta de dois médicos e os que estejam privados de direitos políticos por decisão judicial transitada em julgado.

O artigo 138 e o artigo $152^{4}$ do Código Civil de Portugal estabelecem, respectivamente, quais as pessoas que estão sujeitas a interdição e quais estão sujeitas à inabilitação. Cumpre salientar apenas que aos civilmente incapazes justifica-se a restrição, pois para participar politicamente necessita de uma vontade livre e esclarecida, para exercer o direito de sufrágio o indivíduo necessita ter discernimento, ter capacidade para escolher dentre as opções a que considera preferível para orientar a comunidade.

Não podemos olvidar que dentre os interditos ou inabilitados não se encontra o condenado criminalmente. Aqui, observa-se a evolução de Portugal em matéria eleitoral ao vedar a perda automática de direitos políticos como pena acessória decorrente de condenação criminal ${ }^{5}$.

Sob o ponto de vista das incapacidades, a restrição do direito de voto aos condenados não se justifica, pois não existe qualquer necessidade natural (incapacidade civil) ou organizatória: nesse momento vale lembrar que a pessoa que cometeu um ilícito penal - sendo-lhe aplicada ou não a pena privativa de liberdade - não perde a sua capacidade de discernimento ${ }^{6}$. Não está previsto no texto da Lei Fundamental quaisquer exclusões de direito

\footnotetext{
${ }^{4}$ Artigo $138^{\circ}$, n.1 - Pessoas sujeitas a interdição - Podem ser interditos do exercício dos seus direitos todos aqueles que por anomalia psíquica, surdez-mudez ou cegueira se mostrem incapazes de governar suas pessoas e bens. Artigo $152^{\circ}$ - Pessoas sujeitas a inabilitação - Podem ser inabilitados os indivíduos cuja anomalia psíquica, surdez-mudez ou cegueira, embora de caráter permanente, não seja de tal modo grave que justifique a sua interdição, assim como aqueles que, pela sua habitual prodigalidade ou pelo uso de bebidas alcoólicas ou de estupefacientes, se mostrem incapazes de reger convenientemente o seu patrimônio.

${ }^{5}$ Para demonstrar a evolução de Portugal perante outros países coletamos dados do julgamento perante a Corte Européia de Direitos Humanos, Hirst v. the United Kingdom(2005) o qual demonstra que dezoito países permitem o voto de prisioneiros sem restrição, são eles: Albânia, Azerbaijão, Croácia, República Checa, Dinamarca, Finlândia, "na antiga República Iugoslava da Macedónia, Alemanha, Islândia, Lituânia, Moldávia, Montenegro, Holanda, Portugal, Eslovénia, Suécia, Suíça e Ucrânia. Enquanto que em 25 países os presos foram impedidos de votar.

${ }^{6} \mathrm{Na}$ Espanha foi utilizado o argumento de que o recluso assim como o menor de idade e os incapazes não tem capacidade de autodeterminação política e por isso seria legítima a privação do direito de voto e também se utilizou do argumento técnico de que em uma unidade carcerária não seria possível instalar uma sessão eleitoral, segundo o autor Miguel Ángel Presno Linera o primeiro argumento contraia o artigo 25.2 da Constituição Espanhola e que o segundo não procederia pois pode se valer do voto por correspondência. E ainda fala que uma vez alcançado a idade mínima e que seja feito o recenseamento eleitoral (requisito administrativo) o exercício do sufrágio somente poderá ser restringido diante de incapacidade para decidir reconhecida por sentença judicial. A título de informação, segundo o mesmo autor, na Espanha dissocia-se a titularidade de direito e o exercício de direito, ao afirmar que todos são titulares do direito de participar politicamente, porém somente os eleitores (aqueles que estejam em pleno gozo dos direitos políticos ) podem votar. El Derecho de Voto. Madrid: Tecnos, 2003, p. 132,136,143 e 144.
} 
de voto, salvo por incapacidades civis (naturais), como já citado. Desse modo, resta-se evidente que não pode haver incapacidades eleitorais que atinjam a universalidade e a igualdade definidas como inerente ao sufrágio (art. $\left.48^{\circ}, \mathrm{n} .2^{\circ}, \mathrm{CRP}\right)$, pois se isso acontecesse, o próprio conteúdo essencial do direito estaria diminuído (art. 18, . $^{\circ} 3,2^{\mathrm{a}}$ parte, CRP). (MIRANDA, 1995, p.191).

\section{A PERDA DA CAPACIDADE ELEITORALATIVA COMO PENA ACESSÓRIA}

Em Portugal, a lei penal comum define como penas principais, a prisão e demais penas restritivas de liberdade (regime de prova), a multa, a admoestação e a prestação de trabalho a favor da comunidade e, como penas acessórias, a demissão da função pública, a interdição do exercício de profissão, as incapacidades eleitorais, a incapacidade para exercer outros direito (Código Penal, art. 40 e seguintes).

O objetivo do artigo 30, n. $^{\circ} 4$ da Constituição Portuguesa foi retirar às penas todo o caráter infamante e evitar que a atribuição de efeitos automáticos estigmatizantes prejudique a readaptação social do cidadão que cometeu um ilícito penal.

Sobre a proibição de efeitos necessário das penas (art. $30 .^{\circ}$, n. $^{\circ} 4, \mathrm{CRP}$ ),

Canotilho $^{7}$ chama a atenção para o fato de que o preceito constitucional proíbe que seja acrescentado de forma automática, de maneira mecânica, independente de decisão juridical, ou seja, por apenas efeito direto da lei ("ope lege”), uma outra pena que se traduz na perda de direitos civis, profissionais ou políticos à condenação. (CANOTILHO; MOREIRA, 2007, p.504). O que não significa dizer que a Constituição proíbe penas acessórias restritivas de direitos politicos, como veremos no item a seguir.

Ainda de acordo com Canotilho, a teleologia intrínseca da norma consiste em retirar os efeitos impossibilitadores da readaptação social do delinguente, e

\footnotetext{
${ }_{7}^{7}$ Cumpre salientar que o precursor da norma constitucional, n. 4 do artigo $30^{\circ}$ foi o artigo 76 (artigo 77, após a revisão ministerial), do Projeto do Código Penal de 1963, cujo teor era "nenhuma pena implica automaticamente a perda de quaisquer direitos civis, profissionais ou políticos". E na ocasião em que se discutia o artigo 76 do mencionado projeto (na 25 a Sessão da Comissão Revisora, de 2 de abril de 1965), o Professor Ferrer Correia pronunciou que o automatismo das chamadas penas acessória "não pode aceitar-se na medida que briga claramente com o fim da pena que se reputa essencial: o da recuperação social do delinqüente. Pois é precisamente o seu caráter automático que lhe confere a natureza de labéu, de pena infamante, de marca indelével". (TORRES, 1986, p.114).
} 
"impedir que, de forma mecânica, sem se atender aos princípios de culpa, da necessidade e da jurisdicionalidade, se decrete a morte civil, profissional ou política do cidadão" (CANOTILHO; MOREIRA, 2007, p.504).

\section{PENAACESSÓRIARESTRITIVA DO DIREITO DE SUFRÁGIO ATIVO E O PRINCÍPIO DA PROPORCIONALIDADE COMO LIMITE DE SUAAPLICAÇÃO}

Em Portugal, a aplicação automática da pena acessória restritiva de direitos políticos é vedada, seja em decorrência da pena aplicada ou do crime praticado. O que está proibido pelo preceito constitucional (art. $30^{\circ}$, n. $^{\circ}$ 4) é o efeito automático, o que não significa dizer que o legislador ordinário está proibido de estabelecer como pena acessória a perda de direitos políticos.

Nesse sentido, o artigo 346 do Código Penal de Portugal dispõe sobre a possibilidade de aplicação de pena acessória restritiva de direitos políticos a quem for condenado pela prática de um crime contra a segurança pública, ficando o condenado incapacitado para eleger Presidente da República, membro de Assembléia Legislativa ou de Autarquia Local. Nesse mesmo sentido as leis eleitorais citadas preveem que não gozam de capacidade eleitoral ativa os cidadãos que tenham sido privados dos direitos políticos por decisão judicial transitada em julgado.

Para que seja aplicada a pena acessória de restrição do direito ao sufrágio são necessários três pressupostos cumulativos: a prática de um crime contra a segurança do Estado, a concreta gravidade do fato $^{8} e$ a sua projeção na idoneidade cívica do agente ${ }^{9}$.

A perda da capacidade eleitoral ativa como pena acessória segundo os penalistas cumpre fins transpenais, pois tem por objetivo proteger o sistema eleitoral contra cidadão cujos fatos evidenciam inimizade ou profundo desrespeito ao Estado Português e, portanto, não devem ser admitidos a participar na formação da vontade popular sobre o destino da comunidade. Pedro Caeiro, ao explicar quando será cabível a censura suplementar contida

\footnotetext{
${ }^{8}$ Os critérios para aferir a concreta gravidade do fato são: gravidade do ilícito, gravidade da culpa, exigências de prevenção geral e especial. (DIAS, 2001, p.332).

${ }^{9}$ Só se justifica privar o agente de seus direitos políticos se através do ato praticado ficar demonstrado um profundo menosprezo pelo status de cidadania, deve ser feita sempre a avaliação dos motivos que levaram à prática do ato. (DIAS, 2001, p.333-334).
} 
na pena acessória, conclui que é "na relação estabelecida entre o cometimento do crime e o abuso ou o mau uso do direito ou faculdade que a ele se liga" (CAEIRO, 1993, p.545).

Não podemos olvidar que a Constituição e os valores jurídicos nela contidos desempenham a função de um quadro de referência e também simultaneamente o critério regulativo do âmbito de uma aceitável e necessária atividade punitiva do Estado (DIAS, 1983, p.16). É o texto constitucional que controla a atividade punitiva do Estado e também estabelece como base da República a vontade popular e a dignidade da pessoa humana. Pertinente essa colocação, visto que se fala do jus puniendi estatal na esfera dos direitos políticos, especificamente no direito de sufrágio ativo.

A Constituição estabelece através da definição dos direitos, liberdades e garantias o quadro dos valores fundamentais da ordem jurídica: tais valores são base dos princípios da política criminal, os quais guiam a atividade jurisdicional, a atividade do intérprete e do legislador penal. Os princípios constitucionais da política criminal são: o princípio da culpa, da necessidade da pena e das medidas de segurança, os princípios da legalidade e da jurisdicionalidade da aplicação do direito penal, o princípio da humanidade e da igualdade (BRITO, 1987, p.199).

Em breve síntese, através do princípio da culpa extrai-se a lógica de que a pena se funda na culpa do agente pela sua ação ou omissão, ou seja, em um juízo de reprovação do agente por não ter agido em conformidade com o dever jurídico. É necessário considerar que a pena se traduz em restrições ou sacrifícios dos direitos fundamentais do "criminoso", cujo respeito é uma finalidade essencial do Estado (art. $2^{\circ}, \mathrm{CRP}$ ), desse modo é indispensável que esse sacrifício seja necessário à paz e à conservação sociais, isto é, à própria defesa dos direitos, liberdades e garantias (BRITO, 1987, p.200).

A validade dos atos estatais são condicionados pela regularidade formal do seu processo de produção e pela concordância material do seu conteúdo com uma "tábua de valores" que lhe é anterior e superior. Sendo esta a posição do Estado frente aos direitos individuais, não parece defensável que cumpra ao Estado limitar esses direitos, ainda que seja em nome da justiça, noutra medida que não seja a necessidade de defesa e proteção dos outros direito individuais (BRITO, 1987, p. 227-228). A noção 
de Estado de Direito em sentido material implica no princípio da necessidade ou máxima restrição das sanções penais.

Desenvolveu-se nas modernas sociedades democráticas e pluralistas a aplicação da pena não como ideia de retribuição, mas sim pautada na exigência de respeito pela dignidade do homem, de modo que sua execução vise à ressocialização do delinquente, oferecendo a ele o máximo de condições favoráveis ao prosseguimento de uma vida sem praticar crimes.

$\mathrm{O}$ artigo $30^{\circ}$, n. ${ }^{\circ}$, da Constituição Portuguesa prevê a conservação dos direitos fundamentais aos condenados sujeitos à pena ou medida de segurança privativas da liberdade, ressalvando-se as limitações inerentes ao sentido da condenação e as exigências próprias da respectiva execução. É preciso saber que algumas limitações são inerentes à pena de prisão, como a privação da liberdade, impossibilidade de deslocação, de emigração, etc e outras restrições com observância dos princípios da necessidade e da adequação são justificáveis pela própria execução da pena, tais como, limites à liberdade de correspondência, de expressão, de reunião, de manifestação.

Fala-se em limitações inerentes ao sentido da condenação, surgindo, então, a seguinte indagação: o sentido da condenação à pena privativa de liberdade é excluir o cidadão da participação política, cerceando a sua capacidade eleitoral ativa? Pelo exposto, nota-se que a resposta é negativa, afinal a perda de direitos fundamentais pode levar o cidadão à morte política, o que é incompatível com o sentido objetivo e subjetivo do catálogo dos direitos, liberdades e garantias consagrado na Constituição Portuguesa. O fato de estar cumprindo pena privativa de liberdade não só impede como se exige do Estado a instalação de sessões eleitorais ou a permissão do voto por correspondência (SIERRA, 2008, p.129).

A dignidade da pessoa permanece ainda que em face de comportamento ilícitos e sancionados pela ordem jurídica. Desse modo a impossibilidade de exercer o direito de voto é atentatória da garantia constitucional prevista no artigo $30^{\circ}, \mathrm{n} .5$, da Constituição.

Cumpre ressaltar que a função do direito penal só pode ser a proteção de bens jurídicos, não a decisão de controvérsias morais, o reforço de normas morais ou a tutela de qualquer moral. Assim, a soma dos males produzidos pelas penas não deve ser superior aos prejuízos causados pelos delitos e que sendo a pena um mal necessário ela deve ser utilizada com parcimônia (BENTHAM, 2005, p.46). Ora, no Estado de Direito, a "qualidade de pessoa" cabe a todos os seres humanos em virtude da sua condição 
humana, visto que "nos outros, não há inimigo. Nos outros há pessoas" (RODRIGUES, 2006, p.310).

Ressaltado o papel desempenhado pelo direito de sufrágio ativo em um Estado Democrático de Direito, convoca-se o princípio da proporcionalidade para orientar a decisão judicial sobre a real necessidade do cabimento da pena acessória que cerceia o direito de participação política do cidadão.

O reconhecimento da dupla dimensionalidade dos direitos fundamentais resulta da percepção de uma tarefa básica a ser cumprida por uma comunidade política, qual seja, a harmonização dos interesses de seus membros individualmente considerados com os interesses de toda a comunidade. É na dimensão objetiva dos direitos fundamentais que aparece a princípio da proporcionalidade.

O princípio da proporcionalidade pode ser decomposto em três subprincípios, quais sejam, o da idoneidade ou adequação, o da necessidade ${ }^{10}$ e o princípio da racionalidade ou proporcionalidade stricto sensu.

Para este último, deve-se estabelecer uma correspondência entre o fim a ser alcançado por uma disposição normativa e o meio empregado, significando que não se deve ferir o conteúdo essencial de direito fundamental para afastar o desrespeito intolerável do valor/princípio da dignidade humana ${ }^{11}$. Assim sendo, a imposição da pena principal alcançará, por si, só os objetivos da norma penal, enquanto a atribuição suplementar da pena acessória feriria o conteúdo essencial do direito fundamental de sufrágio ativo.

No que se refere à restrição do direito de voto, o artigo 25 , alínea " $b$ " do Pacto Internacional dos Direitos Civis e Políticos é claro ao dizer que cabe ao Estado tomar medidas eficazes para garantir que as pessoas possam

\footnotetext{
${ }^{10} \mathrm{O}$ princípio da idoneidade ou adequação refere-se à existência de um meio adequado à prossecução do fim consignado pela norma, ou melhor, perante um bem juridicamente protegido, a intervenção ou a providência a adotar pelo órgão competente tem de estar em correspondência com ele. Pelo princípio da necessidade, temos que dentre os meios possíveis de serem escolhidos in abstrato deve optar pelo que melhor satisfaz in concreto, com menos custos ou mais benefícios. Conceitos extraídos de Miranda (2008, p.284-285).

${ }^{11}$ Guerra Filho (1996, p.259). Apenas para efeito didático achamos por bem transcrevermos o ensinamento do doutor Vieira de Andrade sobre o conceito de núcleo essencial (conteúdo essencial) de direitos fundamentais. Segundo o autor corresponde às faculdades típicas que integram o direito, tal como é definido na hipótese normativa, e que correspondem à projeção da idéia da dignidade humana individual na respectiva esfera da realidade- abrange aquelas dimensões dos valores pessoais que não Constituição visa em primeira linha proteger e que caracterizam e justificam a existência autônoma daquele direito fundamental. (ANDRADE, 2001 p.172).
} 
exercer o seu direito de voto. Ora, quando o recenseamento é necessário, como é o caso de Portugal, essa inscrição deve ser facilitada, inclusive para os que estão detidos, e nenhum obstáculo deve ser imposto.

Entretanto, será a seguir demonstrado que, diferentemente de Portugal, a restrição do exercício do direito de sufrágio está constitucionalmente limitado, em flagrante ofensa aos direitos fundamentais do sujeito inserido no sistema penal.

\section{DIREITO AO SUFRÁGIO NO BRASIL: DA CONDIÇÃO DO PRESO DEFINITIVO E DO PROVISÓRIO}

No Brasil, exercício do direito de sufrágio sofre severas restrições. Ainda que a Constituição Federal de 1988 aponte como regra, em seu artigo 15, a impossibilidade de cassação do exercício do voto, traduz em seus incisos as hipóteses que autorizam a suspensão desse direito/dever. No presente estudo, importa o contido no inciso III, que aponta que a condenação criminal transitada em julgado, enquanto durarem seus efeitos, afasta a possibilidade de manifestação de direitos políticos.

Da disposição legal acima destacada, infere-se que o trânsito em julgado da sentença penal condenatória autoriza que seja atribuído ao sujeito participante do processo jurisdicional uma nova qualificação social. Isto porque, o réu deixa de poder exercer suas prerrogativas políticas, que permanecem suspensas até o cumprimento da sanção imposta na decisão, não importando, a princípio, qual a natureza da pena aplicada.

Nessa linha, o Código Eleitoral Brasileiro (BRASIL, 1965) dispõe como causa de cancelamento do direito à participação no sufrágio a existência de condenações definitivas, o que também impede a possibilidade de alistamento de sujeitos que estejam privados, temporariamente ou em definitivo de direitos políticos (art. $5^{\circ}$, inciso III), ressalvando que, nesses casos, somente podem ser restabelecidos diante do cumprimento ou extinção da sanção penal ${ }^{12}$.

Ocorrendo uma das hipóteses previstas na Constituição Federal, remetem-se automaticamente as certidões condenatórias definitivas ao juiz eleitoral competente - daí a discussão acerca da legitimidade de

\footnotetext{
${ }^{12}$ Nesse sentido, transcreve-se a Súmula 09 do TSE: “A suspensão de direitos políticos decorrente de condenação criminal transitada em julgado cessa com o cumprimento ou a extinção da pena, independendo de reabilitação ou de prova de reparação dos danos".
} 
aplicação imediata do preceito - que determinará sua inclusão no sistema de dados, para que aquele que estiver privado de seus direitos políticos, seja definitivamente (perda), seja temporariamente (suspensão), não figure na folha de votação dos anos eleitorais seguintes.

Desse excerto, duas são as principais ponderações verificáveis no ordenamento brasileiro que devem ser destacadas para a explanação no presente texto: a) a situação constitucionalmente autorizada de exclusão do sujeito que transgride regras penais e tem contra si a instauração de um procedimento penal que, quando finalizado (ou irrecorrível), afasta tal ator da esfera de participação política, e b) a situação dos sujeitos detidos provisoriamente em estabelecimentos penais que não exercem o direito de voto porque não é instrumentalizado pelo Estado.

A suspensão dos direitos políticos é efeito automático da condenação criminal transitada em julgado, independentemente de qualquer requerimento do Ministério Público ou de expressa declaração na sentença. Assim, ainda que omissa a decisão judicial a respeito dos direitos políticos do condenado, estarão automaticamente suspensos a partir do momento em que a condenação passa a ter caráter de definitiva.

Importa ressaltar que a suspensão será realizada em qualquer modalidade de sanção penal aplicada na sentença condenatória, visto que a norma constitucional não restringe seus efeitos a hipóteses específicas de condutas praticadas (tal como ocorre em Portugal) ou correlacionadas com o "quantum" e modalidade de penas eventualmente aplicadas. Nesse passo, até mesmo os sujeitos que receberam o benefício da suspensão condicional, ou ainda, aqueles que permanecem com seu status libertatis, pela imposição de regimes menos gravosos de cumprimento da reprimenda (como é o caso do regime aberto) não podem participar do sufrágio. Significa dizer que, mesmo aqueles sujeitos que não foram detidos em estabelecimentos prisionais de regime fechado não podem participar das eleições.

Ainda que seja contestável que a Constituição legitime a suspensão dos direitos políticos dos sujeitos definitivamente condenados, a realidade prisional brasileira consegue, ainda, revelar uma atuação desconforme ao preceito - já criticável ante a restrição de liberdades políticas - visto que também os presos provisórios são impedidos de manifestar sua vontade soberana. Sendo o direito à participação política um preceito constitucional de eficácia plena, passou-se a discutir jurisdicionalmente a ofensa à Carta, 
à medida que parcela da população carcerária não participa do processo político, frise-se, mesmo esse sendo de cunho obrigatório (nos termos do que preceitua o artigo $14, \S 1^{\circ}$, apontado tal condição aos maiores de 18 anos).

Diante da verificável ofensa a direitos fundamentais e visando a operacionar o voto do preso provisório em todo o Brasil, o Tribunal Superior Eleitoral (TSE) passou a editar resoluções que abordassem a temática em causa, tais como a de $n .^{\circ} 21.633$ de 2004 , e a de $n .^{\circ} 22.712$ de 2008 , definindo que os juízes eleitorais, sob a coordenação dos Tribunais Regionais dos respectivos estados, poderão criar seções eleitorais especiais em penitenciárias, a fim de que os detidos provisórios tenham assegurado o direito de sufrágio. Entretanto, importa frisar o caráter facultativo da instrumentalização do exercício das prerrogativas políticas desses sujeitos, o que serviu de amparo para que os magistrados deixassem de assegurar o contido na resolução.

Somente em data de 02 de março de 2010 o Tribunal Superior Eleitoral (TSE) aprovou a Resolução n. 23.219, que regula, de forma impositiva ${ }^{13}$, acerca da necessidade de instalação de seções eleitorais especiais em estabelecimentos penais e de internação de adolescentes para viabilizar o voto de presos provisórios. Nesse sentido, importa destacar que, ainda que a Constituição Federal regule o direito há mais de vinte anos, somente em 2002 possibilitou-se a votação de presos provisórios, pioneiramente em Pernambuco. Ademais, o número de Estados que viabilizaram a participação do preso nas eleições de 2008 se expandiu para 11 estados - o que vale ressaltar, sequer significa apenas a metade dos Estados que compõem a República Federativa.

Interessante explanar que, para a criação do regulamento e com a intenção de ultrapassar as questões práticas acerca da efetivação do direito, inúmeras audiências públicas foram realizadas para a inclusão eleitoral do preso, iniciativa que pressupõe a colocação dos membros da sociedade civil em contato direto com a problemática do cerceamento do direito de voto.

\footnotetext{
${ }^{13}$ Apesar da ausência de previsões sancionatórias decorrentes do descumprimento do documento, a resolução citada contém um artigo que fixa o prazo de 30 dias para que os Tribunais Regionais Eleitorais que não puderem cumprir cronograma estabelecido pelo Tribunal Superior apresentem um cronograma próprio de implantação do sistema de voto dos presos provisórios e adolescentes e informem eventuais dificuldades para adoção dessa providência em todos os estabelecimentos penais. Tudo isso de forma a forçar a implementação do aparato eleitoreiro nos cárceres nacionais, apontando que a não implementação apenas poderá ser legitima se estiver exaustivamente fundamentada.
} 
Ademais, estabeleceu-se, no mesmo sentido, a criação de Convênios entre os Tribunais Regionais Eleitorais e entidades públicas e civis para colaborar com mutirões para a transferência/emissão de documento de identificação dos eleitores detidos.

As justificativas apontadas para afastar o direito de manifestação política do preso provisório alcançam inúmeras searas:

a) perpassam da dificuldade de implementação dos aparatos técnicos necessários para o pleito - que alcançam desde a compra de equipamentos até a necessidade de contratação de profissionais -, invocando, nesse passo, o enorme dispêndio financeiro para criar novas sedes eleitoreiras. Inclusivamente, trata-se de um direto que pouco sensibiliza a população em geral, porque significa gastar dinheiro com uma parcela de sujeitos desviantes, que não contam com o reconhecimento dos demais atores sociais;

b) decorrem de problemas inerentes à política criminal: nos tempos atuais caracterizadores da sociedade do medo, a insegurança afastaria a intenção dos colaboradores eleitorais em adentrar na unidade prisional;

c) aponta para problemáticas de relações de poder no interior do cárcere, à medida que o senso comum infere a possibilidade da vinculação de inúmeros candidatos com organizações criminosas;

d) Como outro empecilho, destaca-se de qual forma poderá o preso tomar conhecimento das propostas dos candidatos, se a utilização de rádios e aparelhos televisores também é limitada no interior das unidades. Ademais, pensa-se em qual seria a forma mais viável de autorizar que os candidatos realizem suas campanhas eleitorais nas unidades prisionais.

e) A Justiça Eleitoral alega dificuldades operacionais decorrente da condição de transitoriedade do detento, visto que não é possível saber com antecedência qual será a sua situação processual no dia da eleição. Da mesma forma, a dificuldade de alistamento ainda pode decorrer do fato de que, se na véspera da eleição for registrado o trânsito em julgado da decisão, o eleitor não mais poderá participar do pleito, ainda que já tenha sido relacionado na listagem dos votantes.

Entretanto, importa destacar que alguns dos problemas acima elencados podem ser ultrapassados. Primeiramente, para lidar com os funcionários da seara eleitoral que temem em participar de pleitos nas unidades carcerárias, e bem como para evitar a contratação de profissionais, apontam-se algumas soluções, já para o pleito deste ano no Brasil: 
a) os próprios detidos podem colaborar com o procedimento formal, sendo candidatos a mesários e coordenadores das eleições nos presídios.

b) através de convênios - conforme previsão do artigo $7^{\circ}$, Resolução n. ${ }^{\circ}$ 23.219 - e ações voluntárias, exemplificando nesse sentido que a atuação da seccional da Ordem dos Advogados do Brasil de São Paulo, que incentiva advogados e estagiários de direito a atuarem como mesários voluntários.

Entretanto, observa-se que o objetivo latente da discussão deixou de ser apreciado: por que retirar do sujeito infrator o direito ao sufrágio? Dos apontamentos destacados, resta evidente que o sistema eleitoral do Brasil retira, em flagrante desacordo com a previsão constitucional, a prerrogativa de exercício de manifestação política do sujeito definitivamente condenado.

Inicialmente, importa destacar que a Constituição Brasileira sustenta, como princípio fundamental tutelado em seu artigo $5^{\circ}$, inciso LVII, $a$ presunção de inocência de todos os sujeitos, ao garantir que "ninguém será considerado culpado até o trânsito em julgado de sentença penal condenatória". Desde logo, constata-se que o réu que ainda não tem contra si uma sentença penal condenatória transitada em julgado pode e deve exercer o direito de votar e de ser votado, em exaltação à sua cidadania e aos postulados constitucionais que legitimam o exercício político em igualdade de condições, quando comparados àqueles que estão em liberdade.

Ainda, o preceptivo constitucional que aponta para o afastamento dos direitos políticos de todos os sujeitos definitivamente sentenciados, parece desconsiderar o conteúdo garantístico dos princípios da proporcionalidade e da individualização da pena (artigo $5^{\circ}$, inciso XLVI da Constituição Federal).

A ofensa desses postulados advém do efeito automático de suspensão de direitos decorrente de todas as sentenças condenatórias com força de definitivas. Nesse sentido, o cerceamento do direito reveste-se de uma feição de pena acrescentada, que não se coaduna com o fato ilícito praticado. Uma vez que os condenados possuem o mesmo tratamento -, visto que não deixa ao magistrado que preside o caso concreto qualquer margem para apreciar a real necessidade de afastamento do direito -, deixa-se de igualar os desiguais dispensando a todos uma mesma sanção, afastada da correlação entre a prática do comportamento desviante e a necessidade/ merecimento da intervenção punitiva no caso concreto.

É preciso fazer com que agentes públicos se comprometam com o sistema prisional, e tal postura somente será adquirida quando o detento 
tornar-se eleitor. Se assim fosse, fomentar-se-ia a discussão e a formação crítica dos presos, que até mesmo poderiam se unir em prol de um objetivo comum: a eleição de um representante parlamentar de suas reivindicações. Poderiam ser ouvidos sem recorrerem a insurreições violentas. E um dado importante: teriam valor numérico suficiente para chamar a atenção dos candidatos e incluir preocupações do sistema prisional nas pautas das campanhas eleitorais.

\section{CONCLUSÃO}

Diante do exposto, evidencia-se que, em Portugal, o artigo $30,{ }^{\circ}{ }^{\circ} 4$ da Constituição proíbe que a perda dos direito políticos dos sentenciados seja consequência automática da condenação. Entretanto, a cassação do direito de sufrágio (ativo) pode ser aplicada de forma acessória nas condenações criminais, desde que seja necessária para melhor censurar àqueles crimes que tenham relação com violações dos deveres de cidadania ou de responsabilidade política.

Assim, na medida em que é possível que o juiz aplique tal pena, devese convocar o princípio da proporcionalidade para guiar a discricionariedade do órgão judicante, o qual deve buscar alcançar os resultados devidos sem ferir o conteúdo essencial do direito fundamental, evitando o desrespeito intolerável do valor/princípio da dignidade humana.

De outro lado, observa-se que no ordenamento nacional, a restrição do direito de sufrágio é efeito automático de qualquer sentença condenatória transitada em julgado - e, portanto, com força de definitiva -, situação legitimada pela norma constitucional (artigo 15, inciso III) (BRASIL, 1988).

Não fosse apenas essa a ofensa ao cidadão, ainda verifica-se que os sujeitos detidos provisoriamente também estão afastados de seu direito de participação política, uma vez que o Estado não viabiliza o direito ao voto daqueles inseridos numa unidade carcerária. É patente a ofensa à dignidade visto que, diante da ideia de presunção de inocência, a sanção prevista no artigo 15, III, da CF jamais poderia ser imputada a estes sujeitos.

Em síntese, e como crítica, pretendeu-se demonstrar que o direito de sufrágio ativo deve ser analisado no contexto de uma República que é um Estado de Direito Democrático e tem como base a dignidade da pessoa humana relacionada com a garantia constitucional dos direitos fundamentais 
e a vontade popular ligada com o sistema democrático.

A participação dos cidadãos na vida política efetiva-se diretamente (democracia direta) ou através de órgãos representativos, eleitos pelos cidadãos (democracia representativa), através do direito de sufrágio ativo, que consiste em uma das modalidades previstas pela Constituição. Significa dizer que, é através deste direito que o cidadão exterioriza sua vontade, escolhendo os representantes que exercerão o poder em seu nome. Desse modo o direito de participar politicamente através do sufrágio ativo é um meio para assegurar a liberdade inerente à condição de pessoa.

\section{REFERÊNCIAS}

ALEXY, Robert. Teoria dos direitos fundamentais. Tradução de Virgílio Afonso da Silva. São Paulo: Malheiros, 2008.

ANDRADE, José Carlos Vieira. Os direitos fundamentais na constituição portuguesa de 1976. 2. ed. Coimbra: Almedina, 2001.

BENTHAM, J. Traité de législation civile et pénale. In: CUSSON, Maurice. Criminologia. Porto: Casas das Letras, 2005. p.46-47.

BRASIL. Constituição (1988). Constituição da República Federativa do Brasil. Disponível em: $<$ http://www.planalto.gov.br/ccivil_03/constituicao/ constituicao.htm>. Acesso em: 6 jul. 2013.

BRASIL. Lei $\mathbf{n}^{\mathbf{0}}$ 4.737, de 15 de julho de 1965. Institui o Código Eleitoral. Disponível em: $<$ http://www.planalto.gov.br/ccivil_03/leis/ 14737.htm>. Acesso em: 5 jul. 2013.

BRITO, José Souza. A lei penal na constituição. In: MIRANDA, Jorge (Coord.). Estudos sobre a constituição. Lisboa: Livraria Petrony, 1987. p.197-254.

CAEIRO, Pedro. Qualificação da Sanção de inibição da faculdade de conduzir prevista no artigo $61, \mathrm{n}^{\circ}{ }^{\circ}$, alínea "d", do código da estrada. Revista Portuguesa de Ciência Criminal, Lisboa, ano 3, n.1, p.543-572, jan./mar. 1993. 
CANOTILHO, José Joaquim Gomes. Direito constitucional e teoria da constituição. 7. ed. Coimbra: Almedina, 2003.

CANOTILHO, José Joaquim Gomes; MOREIRA, Vital. Constituição da república portuguesa anotada. 4. ed. Coimbra: Coimbra, 2007.

DIAS, Jorge de Figueiredo. Comentário conimbricense do código penal: parte especial. Coimbra: Coimbra, 2001.

. Os novos rumos da política criminal e o direito penal português do futuro. Revista da Ordem dos Advogados, Lisboa, ano 43, p.5-40, 1983.

GUERRA FILHO, Willis Santiago. Notas em torno ao princípio da proporcionalidade. In: MIRANDA, Jorge. Perspectivas constitucionais. Coimbra: Coimbra, 1996. p.249-261.

HÄRBELE, Peter. La dignidade como fundamento de la comunidad estatal. In: SEGADO, Francisco Fernandéz. Dignidad de la persona, derechos fundamentales, justicia constitucional. Madrid: Dykinson, 2008. p.208217.

MIRANDA, Jorge. Manual de direito constitucional. 4. ed. Coimbra: Coimbra, 2008.

. Estudos de direito eleitoral. Lisboa: LEX Edições Jurídicas, 1995.

MORAES, Alexandre. Constituição do Brasil interpretada e legislação constitucional. São Paulo: Atlas, 2002.

SARLET, Ingo Wolfgan. A eficácia dos direito fundamentais. Porto Alegre: Livraria dos Advogados, 2006.

SIERRA, María. La figura del elector en la cultura política del liberalismo español. Revista de Estudios Políticos, Madrid, n.133, p. 117-142, jul./sept. 2008. 
TORRES, Mário. Suspensão e demissão de funcionários ou agentes como efeito de pronúncia ou condenação criminais. Revista do Ministério Público, Lisboa, ano 7, n. 25, p.114-140, jan./mar. 1986.

Recebido em: 2013-05-18 Aprovado para publicação em: 2013-08-13

Como citar: OLIVEIRA, Cristina Rego; CUNHA, Stella Furlanetto Mattos. A perda do direito de sufrágio ativo como efeito da condenação penal: uma abordagem comparativa entre Brasil e Portugal. Revista do Direito Público, Londrina, v.8, n.2, p.197-220, mai/ ago.2013. DOI: 10.5433/1980-511X.2013v8n2p197. 